\title{
Kinesiotherapeutic interventions in diaphragmatic mobility of patients with chronic obstructive lung disease: systematic review
}

\author{
Intervenções cinesioterapêuticas na mobilidade diafragmática de \\ pacientes com doença pulmonar obstrutiva crônica: revisão sistemática
}

\author{
Gilson Rosa de Jesus' ${ }^{1}$ Milena Santos Peixoto', Sidney de Souza Oliveira ${ }^{1,2,3}$ \\ 1. Faculdade de Ciências Empresariais (FACEMP), Santo Antônio de Jesus, BA, Brazil. \\ 2. União Metropolitana de Educação e Cultura (UNIME), Lauro de Freitas, BA, Brazil. \\ 3. Escola Bahiana de Medicina e Saúde Pública, Salvador, BA, Brazil.
}

\begin{abstract}
This study analyzed the pathophysiological impacts of Chronic Obstructive Pulmonary Disease (COPD) on the respiratory system and the benefits of kinesiotherapeutic interventions on diaphragmatic mobility in patients affected by COPD. Systematic literature review, carried out in the Scielo, Medline, VHL, Lilacs and PEDro databases, using the following keywords: Chronic Obstructive Pulmonary Disease, Respiratory Rehabilitation, Kinesitherapeutic Interventions and Diaphragmatic Dysfunction. Only original articles, published between 2009 and 2019, about the benefits of different respiratory physical therapy intervention programs were included. Two examiners analyzed the qualities and evidence of the articles using the PEDro scale. Twelve manuscripts make up the discussion of this work. The present study confirms the beneficial effects of different Kinesiotherapy Intervention programs on physical health and quality of life, reduction of respiratory symptoms and risk of mortality, increased mobility of the rib cage, diaphragmatic functionality, functional capacity and respiratory muscle strength of patients affected by COPD.
\end{abstract}

Key-words: Chronic obstructive pulmonary disease, respiratory rehabilitation, kinesiotherapeutic interventions, diaphragmatic dysfunction.

\section{RESUMO}

Este estudo analisou os impactos fisiopatológicos da Doença Pulmonar Obstrutiva Crônica (DPOC) no sistema respiratório e os benefícios das intervenções cinesioterapêuticas na mobilidade diafragmática em pacientes acometidos pela DPOC. Revisão sistemática de literatura, realizada nas bases de dados Scielo, Medline, BVS, Lilacs e PEDro, utilizando em cruzamentos os seguintes descritores: Doença Pulmonar Obstrutiva Crônica, Reabilitação Respiratória, Intervenções Cinesioterapêuticas e Disfunção Diafragmática. Incluídos apenas artigos originais, publicados entre 2009 e 2019, que versassem sobre os benefícios de diferentes programas de intervenções fisioterapêuticas respiratórias. Dois examinadores analisaram as qualidades e evidências dos artigos por meio da escala PEDro. Doze manuscritos compõem a discussão deste trabalho. O presente estudo confirma os efeitos benéficos de diferentes programas de Intervenções Cinesioterapêuticas sobre a saúde física e qualidade de vida, redução dos sintomas 
respiratórios e do risco de mortalidade, aumento na mobilidade da caixa torácica, funcionalidade diafragmática, capacidade funcional e da força muscular respiratória de pacientes acometidos pela DPOC.

Palavras-chave: Doença pulmonar obstrutiva crônica, reabilitação respiratória, intervenções cinesioterapêuticas, disfunção diafragmática.

\section{Introduction}

According to the Informatics Department of the Brazilian Unified Health System [1], three individuals die every hour due to Chronic Obstructive Pulmonary Disease (COPD), which corresponds to approximately 40,000 deaths per year in the country. Due to the increase in tobacco consumption mainly in developing countries and the aging population in high-income countries, the prevalence is expected to increase worldwide, with the expectation of 4.5 million annual deaths in 2030, however, currently under diagnoses impact the accuracy of pathology-related mortality data [2].

COPD is a preventable and treatable disease, characterized by persistent respiratory symptoms and limited airflow due to abnormalities of the airways or alveolar airways usually caused by significant exposure to harmful particles or gases, that cause a chronic inflammatory response and that can produce changes in the bronchi resulting in chronic bronchitis (defined as the presence of cough and mucus production for at least three months in two consecutive years) and pulmonary emphysema (characterized by destruction of the alveolus) $[2,3]$.

The increase in airway resistance may cause, throughout the evolutionary process of the disease, other pulmonary changes identified by the increase in static lung volumes. This progressive process is recognized as air trapping and has been considered an important limiting factor in diaphragmatic function in patients with COPD [4]. The respiratory system has some muscles, the diaphragm being the main muscle for ventilation and anatomically separates the chest from the abdominal cavity, with differences between the diaphragmatic domes, the right being higher than the left [5]. Craniocaudal movement of this muscle promotes the perfect performance of pulmonary mechanics, making morphological and functional changes in the thoracic and abdominal cavity, resulting in air entering the lungs. It is essential that the diaphragm moves in its entirety and with the ideal length-tension relationship for synergy to occur with the abdominal muscles $[6,7]$.

Over the years, studies have shown that the decrease in diaphragmatic mobility (DM) occurs by reducing this relationship in the apposition zone and in the radius of curvature of the diaphragmatic muscle [8], in addition to promoting changes in volumes and lung capacity, interfere with performance, mobility and conformity of the diaphragm, which loses its dome shape and tends to rectify, reducing its apposition zone and limiting the ventilatory action, normally more evident in the lower portion of the rib cage, which may lead the patient to paradoxical breathing due to the disorder between the thoracic and abdominal compartments [9].

In some studies, it was observed that patients classified as mild COPD had a higher DM when compared to patients classified as severe. The same au- 
thors also observed relationships between DM with functional vital capacity (FVC) and slow vital capacity (SVC). These results support the hypothesis that the reduction in DM may be related to the severity of COPD [10]. The acting of Kinesiotherapeutic Interventions is of fundamental importance, helping in recovery and rehabilitation, seeking to interfere in these mechanisms, improving the functional capacity of the patient and restoring his independence [11].

Based on this information, this review sought scientific evidence to demonstrate and/or prove the benefits of Kinesiotherapeutic Interventions in improving diaphragmatic mobility in patients affected by COPD, justified by the high incidence of individuals affected by COPD, taking into account the pathophysiological impacts caused by respiratory system and the need for physiotherapeutic approaches that are better elucidated and scientifically proven as to their effectiveness, thus facilitating the compliance and rehabilitation of these patients.

\section{Methods}

The present study is characterized as a systematic literature review, carried out with original articles published in scientific journals indexed in the databases Pubmed, Scielo, Medline, BVS, PEDro and Lilacs, in the period from 2009 to 2019, using health descriptors: chronic obstructive pulmonary disease, respiratory rehabilitation, kinesiotherapeutic interventions and diaphragmatic dysfunction and their correlates in English.

The studies that fit the inclusion criteria were selected: a) Original studies; b) Studies in which the participants presented only the diagnosis of COPD; c) Clinical studies that applied physical therapy intervention programs as a form of intervention; Studies were excluded: a) Whose participants had a chronic disease in addition to COPD; b) Studies that described only clinical recommendations; c) Studies that did not describe the intervention performed with the participants; d) Duplicate studies; e) Case reports, doctoral thesis and master's dissertation. Data selection and extraction.

The screening process of the studies was carried out initially by reading the titles. Posteriorly, duplicate articles were excluded and titles and abstracts were read to verify that they met the eligibility criteria of the present study. The articles that met the established criteria were retrieved for reading the full text, reassessment of the eligibility criteria and data extraction regarding a) the author and year of publication, (b) objectives, (c) sample and method of assessing muscle strength, (d) intervention and (e) results of muscle strength (Table I). Lastly, the references of the main studies included in this review were evaluated, in order to verify the existence of unidentified eligible articles in the searches in the selected databases (Figure 1). Resume the process of screening and selecting studies.

The selected studies were submitted by two examiners to a qualitative evaluation of the methodology used through the PEDro scale and were evaluated according to the quality indicators shown on the scale. The application of the PEDro scale in the evaluation of each article results in a final score that can vary from 0 (zero) to 10 (ten), and only the articles that obtained a score equal to or greater than 3 (three) points were used in the present study (Table I).

The information available in the articles included in this review was extracted and summarized in a standardized manner, based on the following 
topics: authors/year of publication, Qualis score, study title, type of study/ sample number, type of intervention, total intervention time and a brief description of the results obtained. After being extracted, the data were allocated in a summary table to facilitate the analysis of the results (Table II).

\section{Results}

The search in the databases initially identified 561 studies of which 207 were excluded because they were review articles, doctoral thesis, master's thesis and case report, 122 articles were excluded because they addressed other pathologies besides COPD, 188 articles were excluded because they did not directly address the topic and 32 studies were excluded because they did not describe applied physical therapy interventions, leaving 12 articles as potentially relevant for this review, as shown in the flowchart below (Figure 1).

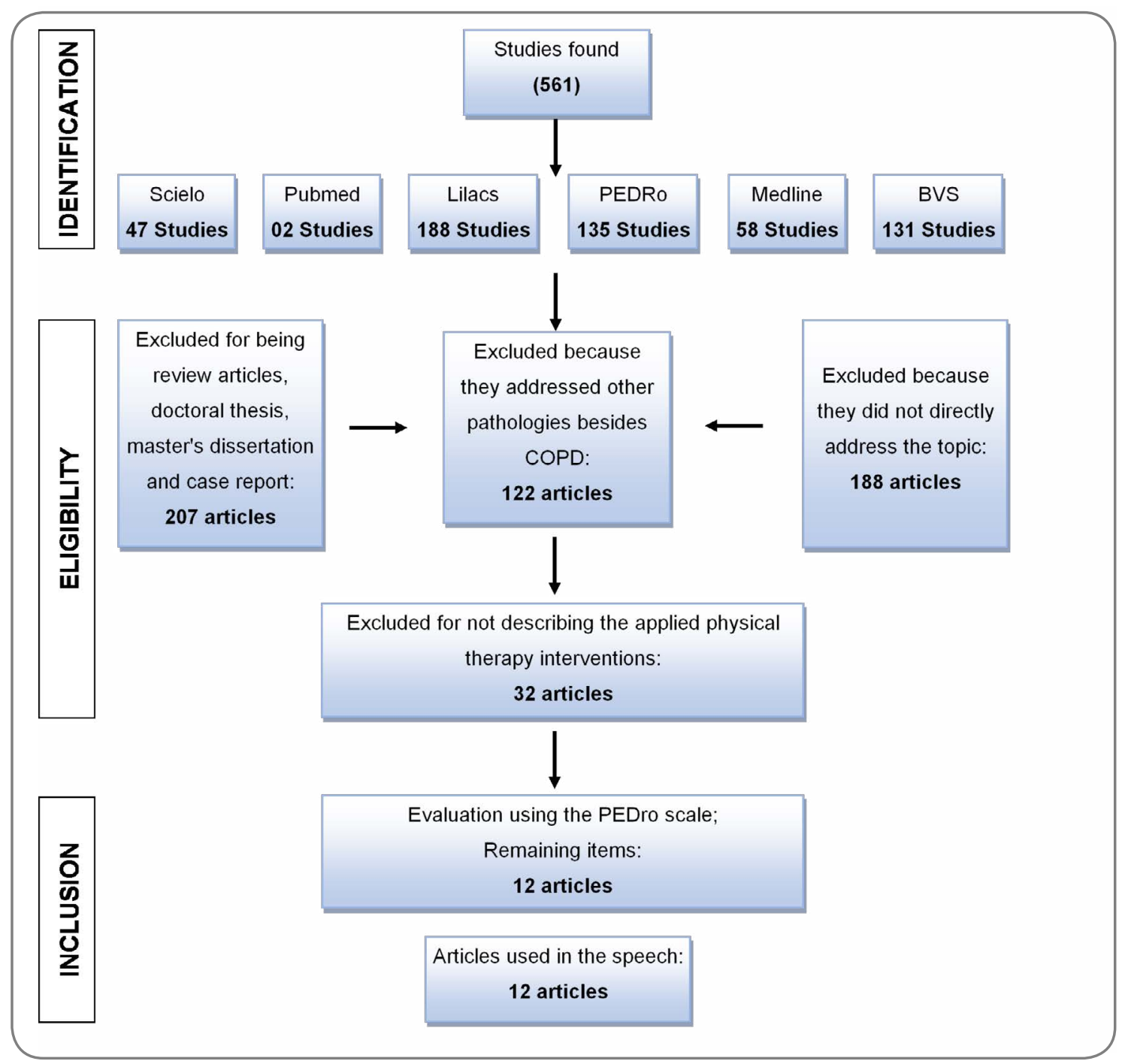

Figure 1 - Flowchart of screening and selection of studies. 
The 12 selected articles were evaluated on the PEDro scale according to the following quality indicators of the evidence presented: 1. specification of the inclusion criteria (item not scored); 2. random allocation; 3. secrecy in the allocation; 4 . Similarity of the groups in the initial or baseline phase; 5 . masking the subjects; 6 . masking those responsible for the intervention; 7. masking the evaluator; 8 . measurement of at least one primary outcome in $85 \%$ of the allocated subjects; 9 . analysis of the intention to treat; 10 . comparison between groups of at least one primary outcome; and 11. reporting of variability measures and estimating parameters for at least one primary variable, who received an assigned point (in relation to presence) or no assigned point (in relation to absence) of the indicators. The articles selected in this study are shown in Table I.

Table I - Presentation of the score of the selected articles, according to the PEDro scale.

\begin{tabular}{|c|c|c|c|c|c|c|c|c|c|c|}
\hline \multirow[t]{2}{*}{ References } & C & C & $\mathrm{C}$ & C & C & C & C & C & C & Score \\
\hline & 2 & 3 & 4 & 5 & 6 & 7 & 8 & 9 & 10 & \\
\hline $\begin{array}{l}\text { Trevisan E } \\
\text { et al. }(2010)\end{array}$ & - & + & - & - & - & + & + & - & + & $4 / 10$ \\
\hline $\begin{array}{l}\text { Fernandes M } \\
\text { et al. }(2011)\end{array}$ & - & + & - & - & - & + & + & + & + & $6 / 10$ \\
\hline $\begin{array}{l}\text { Nohama P } \\
\text { et al. (2012) }\end{array}$ & - & + & - & - & - & + & + & - & + & $4 / 10$ \\
\hline $\begin{array}{l}\text { Wellington P } \\
\text { et al. (2012) }\end{array}$ & - & + & - & - & - & + & + & + & + & $6 / 10$ \\
\hline $\begin{array}{l}\text { Cancelliero-Gaiad et } \\
\text { al. (2013) }\end{array}$ & - & + & - & - & - & + & + & - & + & $4 / 10$ \\
\hline $\begin{array}{l}\text { Cancelliero-Gaiad et } \\
\text { al. (2014) }\end{array}$ & - & + & - & - & - & + & - & - & + & $3 / 10$ \\
\hline $\begin{array}{l}\text { Abdelaal AM } \\
\text { et al. (2015) }\end{array}$ & - & + & - & + & - & + & + & + & + & $7 / 10$ \\
\hline $\begin{array}{l}\text { Beaumont } M \\
\text { et al. }(2015)\end{array}$ & - & + & - & - & - & + & + & + & + & $6 / 10$ \\
\hline $\begin{array}{l}\text { Rocha T } \\
\text { et al. (2015) }\end{array}$ & + & + & - & + & - & + & + & + & + & $8 / 10$ \\
\hline $\begin{array}{l}\text { Elmorsi S } \\
\text { et al. (2015) }\end{array}$ & - & - & + & - & - & - & - & - & + & $3 / 10$ \\
\hline $\begin{array}{l}\text { Martinelli, B } \\
\text { et al. (2016) }\end{array}$ & - & + & - & - & - & + & - & - & + & $3 / 10$ \\
\hline $\begin{array}{l}\text { Nair A } \\
\text { et al. (2019) }\end{array}$ & + & + & - & - & - & + & + & + & + & $7 / 10$ \\
\hline
\end{tabular}

$\mathrm{C}=$ Scoring Criteria. 
Table II - Clinical characteristics of the studies selected for this review.

\begin{tabular}{|c|c|c|c|c|}
\hline References & Objective & Sample and Assessment & Intervention & Results \\
\hline $\begin{array}{l}\text { Trevisan et al., } \\
(2010)\end{array}$ & $\begin{array}{l}\text { To verify the effective- } \\
\text { ness of respiratory mus- } \\
\text { cle and quadriceps train- } \\
\text { ing on the functional } \\
\text { performance of individu- } \\
\text { als with COPD. }\end{array}$ & $\begin{array}{l}9 \text { individuals with } \\
\text { COPD aged between } 49 \\
\text { and } 76 \text { years. } \\
\text { Assessment: MIP, MEP, } \\
\text { 1RM of lower limbs, } \\
6 \mathrm{MWT} \text { and quality of } \\
\text { life SF-36. }\end{array}$ & TMR e MMII. & $\begin{array}{l}\text { Improvement in } \\
\text { all evaluated vari- } \\
\text { ables, with signif- } \\
\text { icant difference in } \\
\text { MIP. }\end{array}$ \\
\hline $\begin{array}{l}\text { Fernandes et al., } \\
\text { (2011) }\end{array}$ & $\begin{array}{l}\text { To investigate the effects } \\
\text { of diaphragmatic breath- } \\
\text { ing on ventilation and } \\
\text { breathing pattern, seek- } \\
\text { ing to identify predictors } \\
\text { of its effectiveness in } \\
\text { patients with COPD. }\end{array}$ & $\begin{array}{l}44 \text { volunteers, distrib- } \\
\text { uted in CG }=15 \text { healthy } \\
\text { patients, } 7 \text { men and age } \\
(60+7) \text {, moderate COPD } \\
\text { group }=14,11 \text { men and } \\
\text { age }(63+7) \text { and Severe } \\
\text { COPD group }=1 \text {, with } 14 \\
\text { men and age }(60+8) \text {. } \\
\text { Assessment: PV, MIP, } \\
\text { MEP, spirometry and } \\
\text { MD. }\end{array}$ & $\begin{array}{l}\text { Diaphragmatic } \\
\text { breathing. }\end{array}$ & $\begin{array}{l}\text { Improvement of } \\
\text { breathing pattern } \\
\text { and ventilatory } \\
\text { efficiency without } \\
\text { causing dyspnea } \\
\text { in patients whose } \\
\text { respiratory muscle } \\
\text { system has been } \\
\text { preserved. }\end{array}$ \\
\hline $\begin{array}{l}\text { Wellington et al., } \\
\text { (2012) }\end{array}$ & $\begin{array}{l}\text { To investigate the effects } \\
\text { of a training program in } \\
\text { diaphragmatic breathing } \\
\text { on thoracoabdominal } \\
\text { movement and on the } \\
\text { functional capacity of } \\
\text { patients with COPD. }\end{array}$ & $\begin{array}{l}30 \text { patients randomly } \\
\text { allocated to } G T=15) \\
\text { and } C G=15 \text { patients all } \\
\text { with COPD. } \\
\text { Assessment: CR/ABD } \\
\text { ratio, diaphragmatic } \\
\text { mobility, } 6 \text { MWT and } \\
\text { health-related quality } \\
\text { of life. }\end{array}$ & $\begin{array}{l}\text { Training pro- } \\
\text { gram of dia- } \\
\text { phragmatic } \\
\text { breathing }\end{array}$ & $\begin{array}{l}\text { Increased mobility } \\
\text { diaphragm, } \\
\text { improvement in } \\
\text { the } 6 \mathrm{MWT} \text { and } \\
\text { quality of life in } \\
\text { the TG. Greater } \\
\text { participation of } \\
\text { the diaphragm } \\
\text { during natural } \\
\text { breathing and im- } \\
\text { proved functional } \\
\text { capacity. }\end{array}$ \\
\hline $\begin{array}{l}\text { Nohama et al., } \\
\text { (2012) }\end{array}$ & $\begin{array}{l}\text { To assess qualitative } \\
\text { and quantitative effects } \\
\text { of transcutaneous syn- } \\
\text { chronous diaphragmatic } \\
\text { stimulation in patients } \\
\text { with COPD. }\end{array}$ & $\begin{array}{l}06 \text { volunteers with } \\
\text { COPD, of both sexes, } \\
\text { aged between } 56 \text { and } \\
71 \text { years. Assessment: } \\
\text { MIP, MEP, pulmonary } \\
\text { function test and appli- } \\
\text { cation of the SGRQ-C } \\
\text { quality of life question- } \\
\text { naire. }\end{array}$ & $\begin{array}{l}\text { Electrical } \\
\text { stimulation } \\
\text { controlled by } \\
\text { the respiratory } \\
\text { signal. }\end{array}$ & $\begin{array}{l}\text { Increased inspi- } \\
\text { ratory muscle } \\
\text { strength, improved } \\
\text { quality of life and } \\
\text { decreased symp- } \\
\text { toms. }\end{array}$ \\
\hline $\begin{array}{l}\text { Cancelliero et al., } \\
(2013)\end{array}$ & $\begin{array}{l}\text { To evaluate the effect of } \\
\text { transcutaneous electrical } \\
\text { diaphragmatic stimula- } \\
\text { tion on the strength and } \\
\text { respiratory muscle en- } \\
\text { durance, thoracoabdom- } \\
\text { inal expandability and } \\
\text { spirometric variables. }\end{array}$ & $\begin{array}{l}\text { 8 COPD patients, aged } \\
(68.5 \pm 6.2), 6 \text { men. } \\
\text { Assessment: MIP, MEP, } \\
\text { axillary, xiphoid and } \\
\text { abdominal cirtometry } \\
\text { and spirometry. }\end{array}$ & $\begin{array}{l}\text { Transcutaneous } \\
\text { electrical dia- } \\
\text { phragmatic sti- } \\
\text { mulation. }\end{array}$ & $\begin{array}{l}\text { Improvement in } \\
\text { respiratory mus- } \\
\text { cle strength and } \\
\text { thoracoabdominal } \\
\text { expandability. }\end{array}$ \\
\hline
\end{tabular}


Table II - Clinical characteristics of the studies selected for this review (continuation).

\begin{tabular}{|c|c|}
\hline References & Objective \\
\hline $\begin{array}{l}\text { Cancelliero et al., } \\
\text { (2014) }\end{array}$ & $\begin{array}{l}\text { Compare ventilatory } \\
\text { parameters during Di- } \\
\text { aphragmatic Breathing } \\
\text { and Pilates Breathing } \\
\text { in COPD patients and } \\
\text { healthy adults. }\end{array}$ \\
\hline
\end{tabular}
Sample and Assessment

$\mathrm{EG}=15$ patients with moderate to severe COPD, 8 men and $\mathrm{CG}=15$ healthy male and female patients aged between 40 and 80 years. Assessment: Time, volume and thoracoabdominal coordination.

Intervention

Diaphragmatic Breathing and Pilates Breathing.

195 male patients, randomly divided into a diaphragmatic manipulation group (group $\mathrm{A} ; \mathrm{n}=$ 46), rib group (group B; $\mathrm{n}=53$ ), both procedures (group C; $\mathrm{n}=50$ ) and control group (group $\mathrm{D} ; \mathrm{n}=46$ ). Assessment: FVC, FEV1, FC, 6MWT.

Beaumont et al., Demonstrate the effec(2015) tiveness of IMT in dyspnea using the Borg scale and the multidimensional dyspnea profile questionnaire at the end of a 6MWT in COPD patients with PImax $=85 \mathrm{~cm} \mathrm{H}_{2} \mathrm{O}$ ( $95 \%$ of the predicted value (predicted.

\begin{tabular}{ll}
\hline Elmorsi et al., & $\begin{array}{l}\text { To evaluate the effec- } \\
\text { tiveness of inspiratory } \\
\text { muscle training as part } \\
\text { of physical training in } \\
\text { COPD patients }\end{array}$
\end{tabular}

60 male patients, equally divided into 3 groups, GA: Training of lower limbs + IMT, GB: Training of lower limbs and CG: without training. Assessment: MIP, MEP, dyspnea, 6MWT, BODE index and SGRQ-C.

Rocha et al., Evaluate whether the (2015) Manual Diaphragm Release Technique improves diaphragmatic mobility after a single treatment or cumulatively and whether it improves exercise capacity, MRP and the kinematics of the chest wall and abdomen.
32 randomized patients with COPD without inspiratory muscle weakness (MIP> 60 cmH2O) Assessment: Dyspnea, Borg. MDP, 6MWT and MIP.
Diaphragm and Increase in VF and ribs manipula- $\quad$ HR. tion
Results

DB increased PV, breathing movements, $\mathrm{SpO}_{2}$ and decreased RF. $\mathrm{PB}$ increased PV in healthy patients and increased $\mathrm{SpO}_{2}$ in both groups.
IMT and standardized pulmonary rehabilitation program.
Improvement in the sensory intensity of dyspnea in all patients and MDP in patients with FEV1 $<50 \%$.

\section{0 patients with sta- ble COPD, aged over} 60 years, randomly assigned to $E G=10$ patients (Manual diaphragm release technique and CG $=10$ patients (simulated treatments

Assessment: diaphragmatic mobility, 6MWT, MIP, MEP, abdominal and chest wall kinematics.

$\begin{array}{ll}\begin{array}{l}\text { IMT and pe- } \\ \text { ripheral muscle } \\ \text { training. }\end{array} & \begin{array}{l}\text { IMT + PMT im- } \\ \text { proves MIP, MEP } \\ \text { and distance cov- } \\ \text { ered on the 6MWT } \\ \text { when compared to } \\ \text { isolated TMP. Both } \\ \text { improve dyspnea, } \\ \text { BODE index and } \\ \text { SGRQ-C. }\end{array} \\ \begin{array}{ll}\text { Diaphragm ma- } \\ \text { nual release }\end{array} & \begin{array}{l}\text { Improves dia- } \\ \text { phragmatic mobil- } \\ \text { ity, exercise capac- } \\ \text { ity and inspiratory } \\ \text { capacity. }\end{array} \\ \end{array}$

IMT and pe- $\quad$ IMT + PMT imripheral muscle proves MIP, MEP and distance covwhen compared to isolated TMP. Both BODE index and Improves diaphragmatic mobility and inspiratory capacity. 
Table II - Clinical characteristics of the studies selected for this review (continuation).

\begin{tabular}{|c|c|c|c|c|}
\hline References & Objective & Sample and Assessment & Intervention & Results \\
\hline $\begin{array}{l}\text { Martinelli et al., } \\
\text { (2016) }\end{array}$ & $\begin{array}{l}\text { Identify the changes } \\
\text { after transcutaneous } \\
\text { electrical diaphragmatic } \\
\text { stimulation by the Rus- } \\
\text { sian current. }\end{array}$ & $\begin{array}{l}13 \text { patients with COPD } \\
\text { grade III and IV, } 11 \text { of } \\
\text { whom were male, white, } \\
\text { aged } 68.46 \pm 11.11 \text { years } \\
\text { Assessment: Anthropo- } \\
\text { metric, respiratory and } \\
\text { functional measure- } \\
\text { ments. }\end{array}$ & $\begin{array}{l}\text { Transcutaneous } \\
\text { diaphragmatic } \\
\text { electrical stim- } \\
\text { ulation by the } \\
\text { Russian current. }\end{array}$ & $\begin{array}{l}\text { Improves respira- } \\
\text { tory and functio- } \\
\text { nal. }\end{array}$ \\
\hline Nair et al., (2019) & $\begin{array}{l}\text { To compare the effects of } \\
\text { diaphragmatic stretching } \\
\text { and manual diaphragm } \\
\text { release technique on dia- } \\
\text { phragmatic excursion in } \\
\text { patients with COPD. }\end{array}$ & $\begin{array}{l}20 \text { patients with mild } \\
\text { and moderate COPD, } \\
\text { allocated to group A or } \\
\text { group B by randomiza- } \\
\text { tion. } \\
\text { Assessment: excursion } \\
\text { of diaphragmatic ex- } \\
\text { pansion }\end{array}$ & $\begin{array}{l}\text { Diaphragmat- } \\
\text { ic stretching } \\
\text { technique and } \\
\text { manual dia- } \\
\text { phragm release } \\
\text { technique }\end{array}$ & $\begin{array}{l}\text { Improvement in } \\
\text { diaphragmatic ex- } \\
\text { cursion before and } \\
\text { after treatment. }\end{array}$ \\
\hline
\end{tabular}

COPD = Chronic Obstructive Pulmonary Disease; $\mathrm{CG}=$ Control Group; GT = WG = Training Group; GDM = Moderate COPD Group; GDG = DPOC Grave Group; TMR = Respiratory Muscle Training; PMT = Peripheral Muscle Training; LL $=$ Muscles of the Lower Limbs; $6 \mathrm{MWT}=6$-minute walk test; $1 \mathrm{RM}=1$ Maximum repetition; MIP = Maximum Inspiratory Pressure; $\mathrm{MEP}=$ Maximum Expiratory Pressure; PRM = Maximum Respiratory Pressures; $\mathrm{BODE}$ Index = Body Mass-Index; Airflow Obstruction; Dyspnea and Exercise Capacity; SGRQ-C = St George's Respiratory Questionnaire for COPD Patients; SF-36 = Short Form-36 Questionnaire; FEV1 = Forced Expiratory Volume in the first second; RD $=$ Diaphragmatic Breathing; $\mathrm{RP}=$ Pilates breathing; $\mathrm{MD}=$ Diaphragmatic Mobility; $\mathrm{PV}=$ Lung Volume; $\mathrm{PV}=$ Ventilatory Functions; $\mathrm{CF}=$ Functional Capacity; FVC = Forced Vital Capacity; $\mathrm{SpO} 2=$ Peripheral Oxygen Saturation; FR $=$ Respiratory Rate; $\mathrm{HR}=$ Heart Rate; $\mathrm{PD}=$ multidimensional profile of dyspnea; $\mathrm{RC} / \mathrm{ABD}=$ Relationship between the rib cage and abdominal movement.

\section{Discussion}

According to studies, the reduction in diaphragmatic mobility (MD) is one of the main risk factors for increased mortality in patients with COPD. Thus, interventions that encourage the use of specific techniques that aim to increase the mobility of the diaphragm and rib cage should be prioritized [9]. The results found in this systematic review point to the acute and chronic benefits of the various techniques of Kinesiotherapeutic Interventions in the diaphragmatic mobilization of patients with COPD, showing the immense importance it has for the rehabilitation of these patients [12]. Studies have shown that techniques such as diaphragmatic breathing [19-21,23,24] electrical stimulation [13-15] and inspiratory muscle training [16-18] promoted improvements in diaphragmatic mobility $[14,20,22,24]$ among other benefits such as increased inspiratory muscle strength $[13,14,16,17]$.

On electrical stimulation techniques, the study by Nohama et al. [13], showed that after 10 sessions lasting 20 minutes of synchronized transcutaneous diaphragmatic stimulation, an electrical stimulation system controlled by the respiratory signal, generated an increase in inspiratory muscle strength in all patients, improved quality of life and decreased symptoms. Similarly, Cancelliero-Gaiad et al. [14] evaluated 8 patients with COPD, using transcutaneous electrical diaphragmatic stimulation, showing that after 12 sessions lasting 30 minutes each, there was an increase in MIP, MEP and thoracoabdominal expandability without interfering with spirometric variables, also showing that these increases were maintained for four weeks after the completion of the in- 
tervention. Corroborating with the studies above, Martinelli et al. [15] aiming to identify changes after transcutaneous electrical diaphragmatic stimulation by the Russian current in 13 patients with COPD, it was found that after 30 sessions lasting 30 minutes, patients showed improvement in minute volume, BODE index (Body Mass Index, Airflow Obstruction, Dyspnea and Exercise Capacity) which is a multigrade system used primarily as a predictor of mortality risk in COPD patients and in the distance covered in the 6-minute Walk Test (6MWT). Although these are studies without a control group, it is possible to infer that electrostimulation may be a viable therapeutic alternative to recover the clinical condition of inspiratory muscle weakness and limitations in thoracoabdominal mobility observed in patients with COPD.

Another technique that can be used to improve diaphragmatic mobility in patients with COPD, it is inspiratory muscle training (IMT) that may or may not be associated with lower limb muscle training (lower limbs). In this sense, Trevisan et al. [16] verified the effectiveness of respiratory muscle and quadriceps training on the functional performance of 9 individuals with COPD, noting that after 16 sessions, patients showed improvement in MIP, distance covered on the $6 \mathrm{MWT}$, quadriceps muscle strength, functional capacity and quality of life. The training of the inspiratory muscles and quadriceps proved to be beneficial to the functional performance of individuals with COPD, suggesting the use of respiratory and peripheral muscle strengthening as a supporting resource in the treatment of these individuals. Following this reasoning, Elmorsi et al. [17] assessed the effectiveness of inspiratory muscle training as part of physical training in 60 male patients with COPD, divided into 3 groups. After 8 weeks of intervention, it was noted that the IMT associated with peripheral muscle training led to a significant improvement in MIP, MEP and distance covered in the $6 \mathrm{MWT}$ compared to isolated peripheral muscle exercise training. However, both improved dyspnea, the BODE index (Body Mass-Index, Airflow Obstruction, Dyspnea and Exercise Capacity) which is a multigrade system used primarily as a predictor of mortality risk in COPD patients and the SGRQ-C (St George's Respiratory Questionnaire for Copd Patients) a version shorter derived from the original version SGRQ (St George's Respiratory Questionnaire) after detailed analysis of data from large studies in COPD and addresses aspects related to three domains: symptoms, activity and psychosocial impacts that respiratory disease inflicts on the patient without significant differences between the two groups. The study showed that IMT offers additional benefits when associated with peripheral muscle training for patients with COPD and with weakness of inspiratory muscles. However, in patients without inspiratory muscle weakness ( $\mathrm{MIP} \geq 60 \mathrm{cmH} 2 \mathrm{O}$ ) when assessing dyspnea, MIP and 6MWT, Beaumont et al. [18], compared IMT with aerobic exercise associated with upper and lower muscle training in 34 patients divided into 02 groups, with COPD and without inspiratory muscle weakness ( $\mathrm{MIP} \geq 60 \mathrm{cmH} 2 \mathrm{O}$ ), after 15 30-minute sessions, the IMT improved FEV $1<50 \%$ of the predicted value, while no benefit was seen in patients with FEV1 $>50 \%$ predicted. IMT did not improve dyspnea or the functional parameter in COPD patients with PImax $\geq 60 \mathrm{cmH} 2 \mathrm{O}$, However, in the subgroup of patients with FEV1 $<50 \%$ predicted, these items have been significantly improved. Thus, we can suggest that IMT is more effective in improving dyspnea and exercise tolerance when used in patients with COPD and $\mathrm{MIP}<60 \mathrm{cmH} 2 \mathrm{O}$. 
Diaphragmatic breathing (DB) is also a technique widely used in pulmonary rehabilitation of patients with COPD, with the aim of improving abdominal movement and reducing chest excursion time and the activity of respiratory muscles in the rib cage, however, it has been little studied in the scientific literature. Thus, when addressing the breathing patterns that aim to raise awareness of the abdominal thoraco breathing movements, improve the movement of the rib cage, optimize the functionality of the respiratory muscles and promote the improvement of pulmonary ventilation, Fernandes et al. [19] investigated the effects of diaphragmatic breathing on pulmonary ventilation and on the breathing pattern of 44 patients with moderate and severe COPD. The authors applied DB every day ( 4 minutes of natural breathing +2 minutes of $\mathrm{DB}+4$ minutes of natural breathing) and after 4 sessions, DB was associated with a significant increase in tidal volume (VC) and reduction in respiratory rate (RR), providing greater ventilation and oxygen saturation (SPO2), reduction in ventilation of dead space and the ventilatory equivalent of carbon dioxide. Despite the small number of sessions, diaphragmatic breathing was able to improve breathing pattern and ventilatory efficiency without causing dyspnea in patients with severe and moderate COPD whose respiratory muscular system is preserved. Following this idea, Wellington et al. [20] aiming to identify the benefits of diaphragmatic breathing training in abdominal mobility, evaluated 30 patients divided into 2 groups. The results showed that after 12 sessions, the intervention group when compared to the control group, showed greater abdominal movement during natural breathing, reduction in the relationship between the rib cage and abdominal movement, increase in the distance covered in the $6 \mathrm{MWT}$, improvement in SGSQ-C. The diaphragmatic breathing training program for patients with COPD induced increased participation of the diaphragm during natural breathing, resulting in an improvement in the patients' functional capacity. These results underscore the importance of DB as a kinesiotherapeutic intervention for adjuvant treatment for patients with COPD. In order to compare ventilatory parameters during $\mathrm{DB}$ and pilates breathing (PB), Cancelliero-Gaiad et al. [21] evaluated 15 patients affected by COPD and 15 healthy, performing natural breathing, DB and $\mathrm{PB}$. The results showed that DB had positive effects, such as increased lung volumes, respiratory movement and $\mathrm{SpO} 2$ and reduced respiratory rate. Although there were no changes in volume and time measurements during PB in COPD, this breathing pattern increased volumes in healthy individuals and increased oxygenation in both groups. In this context, the acute benefits of DB are emphasized as a supportive treatment in respiratory rehabilitation programs.

When talking about manual techniques, the manual release technique improves diaphragmatic mobility, inspiratory capacity and exercise capacity in people with COPD, that said, Rocha et al. [22] evaluated the effectiveness of the manual release technique of the diaphragm in 10 patients with COPD and compared it with 10 patients who underwent simulated treatments, for a total of 6 sessions. After the intervention, the manual release technique of the diaphragm showed a significant increase in diaphragmatic mobility with difference between groups. The manual release diaphragm group had a significant increase in PEmax and PImax. The study suggests that the manual release technique improves diaphragmatic mobility, exercise capacity and inspiratory capacity in people with COPD. In another study, Abdelaal et al. [23] investigated the benefits of diaphragmatic and rib manipulation in ventilatory functions (VF) 
and functional capacity (FC) in patients with COPD. 195 men were randomly divided into ( $\mathrm{GA}=46$ patients) who underwent diaphragmatic manipulation and $(\mathrm{GB}=53$ patients) performing rib elevation, ( $\mathrm{CG}=50$ patients $)$ who performed both procedures and ( $D G=46$ patients as control), all participants received drug treatments. After the intervention that lasted 24 sessions, the results showed that there was a significant increase in the mean values of the 6MWT in Groups A, B and C, with Group C having more significant differences. Thus, diaphragmatic and costal manipulations are effective therapeutic techniques to improve VF and HR in COPD patients, especially if applied together.

In parallel with these techniques, respiratory muscle stretching is another kinesiotherapy intervention used to break the shortening-contraction-shortening cycle, of the diaphragm muscle, present in COPD patients. In a recent randomized study, Nair et al. [24], in which 20 patients were allocated in $\mathrm{GA}=10$ patients undergoing the diaphragmatic stretching technique and $\mathrm{GB}=10$ patients undergoing the manual diaphragm release technique, showed that both groups showed significant improvement in diaphragmatic excursion and chest expansion, meantime, there was no statistically significant difference between the techniques. This result indicates that both can be effective in improving diaphragmatic mobility. It would be better if the authors included a placebo group to assess whether there was a difference between kinesiotherapy interventions and the placebo group.

Although the results are positive, some points must be listed. 1) The evaluation of interventions in adult patients may not adequately represent young people and the elderly; 2) the lack of standardization of the techniques makes the protocols fluctuate and cannot be compared properly; 3 ) analyzing the results based only on statistical precepts, limits clinical inferences and, therefore, the applicability of results in clinical practice; 4) the protocols follow-up period may not have been sufficient to promote responses from a clinical point of view, studies are needed with a longer follow-up time; and 5) the descriptors referring to diaphragmatic mobilization and its synonyms showed low sensitivity and specificity, limiting searches in electronic databases. Although the aspects described need to be further discussed, they do not diminish the importance of the results found.

Therefore, even in the face of the above limitations, we can understand that kinesiotherapy interventions bring benefits to patients affected by COPD, due, because, considered effective as an adjunctive treatment for this disease, especially about diaphragmatic mobility. Even so, we do not rule out the need for more robust studies such as clinical trials with a control group, to better assess the benefits of each kinesiotherapy intervention.

\section{Conclusion}

The results indicate that kinesiotherapeutic interventions lead to a significant improvement in diaphragmatic mobility in individuals with COPD. Other benefits include reduced respiratory symptoms and the risk of mortality, significant improvement in quality of life related to physical health, increased mobility of the rib cage, functionality, functional capacity and respiratory muscle strength.

This work corroborates the importance of incorporating regular breathing programs into conventional COPD treatment, as examples: manual rele- 
ase techniques, respiratory incentive devices, electrostimulation and breathing pattern techniques, directed at increasing the mobility of the rib cage improve chest expansion and exercise capacity in these patients.

\section{Authors' contributions}

Jesus GR, Oliveira SS conceived the study and research design. Jesus GR, Oliveira SS, Peixoto MS analyzed and interpreted the data. Jesus GR, Oliveira SS wrote the manuscript. Oliveira SS made a critical review of the manuscript as the important intellectual content.

\section{Potential conflict of interest}

No potential conflict of interest relevant to this article was reported.

\section{Funding sources}

There were no external funding sources for this study.

\section{References}

1. Datasus. Sistema de informações hospitalares - SIH/SUS. Ministério da Saúde; 2014.

2. Global Strategy for the Diagnosis, (GOLD). Management and Prevention of COPD, Global Iniciative for Chronic Obstructive Lung Disease; 2018.

3. Jardim JR, Oliveira JA, Nascimento O. II Consenso Brasileiro sobre Doença Pulmonar Obstrutiva Crônica - DPOC. J Bras Pneumol 2004;30(1):42.

4. Yamaguti WPS, Paulin E, Shibao S, Chammas MC, Salge JM, Ribeiro M, Cukier A, Carvalho CRF. Air trapping: The major factor limiting diaphragm mobility in chronic obstructive pulmonary disease patients. Respirology 2008;13(1):138-144. https://doi.org/10.1111/j. 1440-1843.2007.01194.X

5. Nason LK, Walker CM, McNeeley MF, Burivong W, Fligner CL, Godwin JD. Imaging of the diaphragm: anatomy and function. Radiographics 2012;32(2):51-70. https://doi.org/10.1148/ rg.322115127

6. Lanzetti CEG, Mitsuya MMF, Lima AB. Análise da força muscular respiratória em pneumopatas crônicos participantes do programa de reabilitação pulmonar. Revista Científica do Uni salesiano 2011;2(4):239-52. http://www.salesianolins.br/universitaria/artigos/no4/artigo41.pdf

7. Pupin MK, Riccetto AGL, Ribeiro JD, Baracat ECE. Comparação dos efeitos de duas técnicas fisioterapêuticas respiratórias em parâmetros cardiorrespiratórios pacientes com bronquiolite viral aguda. J Bras Pneumol 2009;35(9);860-7. https://doi.org/10.1590/s1806-37132009000900007

8. Cassart M, Pettiaux N, Gevenois PA, Paiva M, Estenne M. Effect of chronic hyperinflation on diaphragm length and surface area. Am J Respir Crit Care Med 1997;156:504-8. https://doi. org/10.1164/ajrccm.156.2.9612089

9. Yamaguti WPS, Paulin E, Salge JM, Chammas MC, Cukier A, Carvalho CRF. Diafragmatic dysfunction and mortality in patients with CPOD. J Bras Pneumol 2009;35(12):1174-81. https://doi. org/10.1590/s1806-37132009001200003

10. Davachi B, Lari S, Attaran D, Tohidi M, Ghofraniha L, Amini M, Salehi M, Eskandari E, Yazdi E, Moosavi M, Sm L, Yazdi K. The relationship between diaphragmatic movements in sonographic assessment and disease severity in patients with stable chronic obstructive pulmonary disease. J Cardiothorac Med 2014;(2):187-192.

11. Zanchet RC, Viegas CAA, Lima T. A eficácia da reabilitação pulmonar na capacidade de exercício, força da musculatura inspiratória e qualidade de vida de portadores de doença pulmonar obstrutiva crônica. J Pneumol 2005;31(2):118-24. https://doi.org/10.1590/s180637132005000200006

12. Global Initiative for Chronic Obstructive Lung Disease (GOLD). Global strategy for the diagnosis, management and prevention of chronic pulmonary disease. AJR CCM 2011;187.

13. Nohama P, Jorge RF, Valenga MH. Efeitos da estimulação diafragmática transcutânea sincronizada em pacientes com doença pulmonar obstrutiva crônica (DPOC): um estudo piloto. Rev Bras Eng Bioméd 2012;28(2):103-15. https://doi.org/10.4322/rbeb.2012.018 
14. Cancelliero-Gaiad KM, Ike D, Costa D. Efeito da estimulação diafragmática elétrica transcutânea em parâmetros respiratórios de pacientes com Doença Pulmonar Obstrutiva Crônica. Fisioter Pesqui 2013;20(4):322-9. https://doi.org/10.1590/s1809-29502013000400004

15. Martinelli B, Santos LP, Barrile SR, Iwamoto HCT, Gimenes C, Cavalcanti RDM. Estimulação elétrica transcutânea diafragmática pela corrente russa em portadores de DPOC. Fisioter Pesqui 2016;23(4):345-51. https://doi.org/10.1590/1809-2950/14854823042016

16. Trevisan ME, Porto AS, Pinheiro TM. Influência do treinamento da musculatura respiratória e de membros inferiores no desempenho funcional de indivíduos com DPOC. Fisioter Pesqui 2010;17(3):209-13. https://doi.org/10.1590/s1809-29502010000300004

17. Elmorsi AS, Eldesoky ME, Mohsen MAA, Shalaby NM. Effect of inspiratory muscle training on exercise performance and quality of life in patients with chronic obstructive pulmonary disease. Egyptian Journal of Chest Diseases and Tuberculosis 2016;65:41-6. https://doi.org/10.1016/j. ejcdt.2015.10.006

18. Beaumont M, Mialon P, Le Ber-Moy C, Lochon C, Péran L, Pichon R, Gut-Gobert C, Leroyer C, Morelot-Panzini C, Couturaud F. Inspiratory muscle training during pulmonary rehabilitation in chronic obstructive pulmonary disease: A randomized trial. Chron Respir Dis 2015;12(4):30512. https://doi.org/10.1177/1479972315594625

19. Fernandes M, Cukier A, Feltrim MI. Efficacy of diaphragmatic breathing in patients with chronic obstructive pulmonary disease. Chron Respir Dis 2011;8(4):237-44. https://doi. org $/ 10.1177 / 1479972311424296$

20. Yamaguti WP, Claudino RC, Neto AP, Chammas MC, Gomes AC, Salge JM, Moriya HT, Cukier A, Carvalho CRF. Diaphragmatic breathing training program improves abdominal motion during natural breathing in patients with chronic obstructive pulmonary disease: a randomized controlled trial. Arch Phys Med Rehabil 2012;93(4):571-7. https://doi.org/10.1016/j. apmr.2011.11.026

21. Cancelliero-Gaiad KM, Ike D, Pantoni CBF, Borghi SA, Costa D. Respiratory pattern of diaphragmatic breathing and pilates breathing in COPD subjects. Braz J Phys Ther 2014;18(4):2919. https://doi.org/10.1590/bjpt-rbf.2014.0042

22. Rocha T, Souza H, Brandão DC, Rattes C, Ribeiro L, Campos SL, Aliverti A, de Andrade AD. The Manual Diaphragm Release Technique improves diaphragmatic mobility, inspiratory capacity and exercise capacity in people with chronic obstructive pulmonar y disease: a randomised trial. J Physiother 2015;61:182-9. ttps://doi.org/10.1016/j.jphys.2015.08.009

23. Abdelaal Ashraf AM, Ali Mohamed MI, Hegazy Ibrahim M. Effect of diaphragmatic and costal manipulation on pulmonary function and functional capacity in chronic obstructive pulmonary disease patients: Randomized controlled study. Int J Med Res Health Sci 2015;4(4):841847. https://doi.org/10.5958/2319-5886.2015.00167.8

24. Nair A, Alaparthi GK, Krishnan S, Rai S, Anand R, Acharya V, Acharya P. Comparison of diaphragmatic stretch technique and manual diaphragm release technique on diaphragmatic excursion in chronic obstructive pulmonary disease: a randomized crossover trial. Pulm Med 2019:1-7. https://doi.org/10.1155/2019/6364376 